\title{
The Semiotics of Banyumasan Batik as a Form of Cultural Political Identity of Banyumas Community
}

\author{
Widodo $^{1}$, Hana Saraswati ${ }^{2}$, Ery Iriyanto $^{3}$, Hermi Yuliana Putri $^{4}$ \\ \{widodojawa@mail.unnes.ac.id ${ }^{1}$, hanasaras19@gmail.com² , erybrothers15@gmail.com ${ }^{3}$, \\ hermiyputri13@gmail.com $\left.{ }^{4}\right\}$ \\ Universitas Negeri Semarang, Indonesia ${ }^{1,2,3,4}$
}

\begin{abstract}
The objective of the research is to explore the motifs and meanings of Banyumasan batik as a form of cultural political identity. This research used a descriptive qualitative method. The data were obtained through interview, observation, and documentation. The results of the study showed that Banyumasan Batik is one of the batik with typical motifs that are firm and straightforward. The colour patterns are inspired by plants and animals. Dark dominant colour is a characteristic of inland batik. The beauty of batik appears in the harmonious blend of colours between different fields, lines and contents. It is in contrast to other batik motifs that emphasize more of decorative forms. Banyumasan batik displays forms of symbolism. Typical batik motifs that developed consisted of Lumbon (spice), Jahe Serimpang, Sekar Surya, Serayuan, Pring Sedapur, Tirtatejo, Godong Kosong, Ayam Puger, Babon Angrem, Gemek Setekem, Sida Mukti, Sida Luhur, Sekar Jagad, and Udan Riris. The meaning contained in the motif shows the cultural political identity that developed in the Banyumas community.
\end{abstract}

Keywords: Banyumasan Batik, Meanings, Motifs, Cultural Political.

\section{Introduction}

Banyumasan batik is one of cultural heritages from the community of Banyumas. According to Sholikhah, Purwaningsih, \& Wardani (2017) the distinctive features of Banyumasan batik are a clear and straightforward pattern depicting Banyumas people who are cablaka or being as what they are. The addition of plant and animal ornaments and dominant dark colours also characterize Banyumasan batik as a cultural identity. The beauty of Banyumasan batik can be seen through the neat colour combination and harmony between motifs, patterns and stuffing.

Motifs that have meaning and symbols become interesting things to be explored more deeply from the perspective of semiotics. Etymologically, semiotics comes from the word simeon (Greek) which means sign. Semiotics is one branch that studies the signs and everything related to the sign, such as the sign system and the process that applies to sign users [2].

The semiotic target also examines the sign system, the rules that apply in a particular culture that are hereditary maintained and respected. Signs that are commonly used in cultural communication are those which through motifs. These signs are used to show the politics of cultural identity and special meaning in the form of objects, patterns, motives and meanings.

There are three basic elements in defining meaning that are examined by semiotics i.e. the sign, the reference sign and the sign user. These three elements are examined in the Triangle of 
Meaning model [3]. A sign is something physical that can be captured by the human senses and present other things outside the sign itself. This sign consists of symbols, icons and indexes. Reference marks or commonly called objects is something that becomes a reference from the sign. While the user sign is the meaning that appears in someone's mind about the object to which a sign is referred. Banyumasan batik accommodates three elements of meaning presented in the motif.

The Banyumasan batik motif not only combines the meaning depicted in flora and fauna, but it also depicts the culture of the surrounding community as an inherent cultural political identity. Other cultural influences such as Surakarta and Yogyakarta contribute to the existing motifs.

\section{Research Method}

This research used descriptive qualitative research methods to examine the meaning contained in the motifs. The source of the research data comes from primary and secondary. Primary data were obtained through interviews, observations and documentation that will be carried out at the Gallery of Batik Hadi Priyanto and cultural activists along with batik making sites. Secondary data sources obtained from articles and books that have been published.

Semiotics is used for the analysis of meaning. Text can be verbal or nonverbal in batik. The term of text refers to messages in a collection of signs that are constructed by referring to certain genres or media [4]. The semiotic method is used to dismantle the connotative meaning hidden behind the text which includes culture, experience, and ideology.

According to Putri (2011), qualitative research methods are research procedures that produce descriptive data in the form of written and spoken words from people and observed behavior. Researchers' interpretations come from various thoughts to adjust to reality and understand meaning. Researchers pay attention to processes, events, and authenticity. Researchers are involved with the object being studied [6]. Semiotic analysis using a qualitative approach is subjective so that the research instrument is the researchers themselves [6]. Researchers can describe the signs that are implied in the motifs of Banyumasan batik to understand the symbols contained in batik's motif.

\section{Findings and Discussions}

The existence of Banyumasan Batik has such a long history. The creation of various motifs cannot be separated from the local regional legend entitled Baturraden. Suta, the servant who escaped from the Kutaliman duchy prison with the duchy princess, settled on the Southern slope of Mount Selamet. Since that incident, there is no successor to the throne in duchy position due to the Duke's daughter running away. The cultural character of the Banyumas community which prioritizes egalitarian rather than feudalism cannot be separated from the story of Suta. It seems in their distinctive identity, i.e. cablaka.

All begins from the relationship of a servant and his employer in the legend of Baturraden. Suta who invited the princess to live in a place with a cool air and beautiful natural panorama makes the princess amazed. As the time goes by, while accompanying her husband to open the forest for shelter and farming, the princess made batik with the motifs of flora and fauna within the environment where they lived. From the story then their surrounding community follows the princess to make batik. 
Based on the results of interview with A. Thaifur Anwar, Banyumasan Batik nowadays originated from kademangan or kadipaten (duchy) in Banyumas. The typical Banyumasan Batik motifs were born from these regions. The motifs of flora and fauna cannot be separated from the cultural and cultural identity of the Banyumas people who live in the mountain with all kinds of contents. The distinguishing element is only the addition of red and blue. The results of the crystallized culture into batik motifs turn out to be the cultural identity which is now also used as the cultural political identity, especially on Banyumasan Batik cloth.

\subsection{Motifs and Meanings}

The motifs of Batik depict the Banyumas community that blends with nature. The patterns and motifs of Banyumasan Batik cannot be separated from the aesthetic elements inherent in batik patterns inspired by plants and animals. The coloring process uses dark colors as the base. The colors used are soga brown and wedelan blue, which are generally having black as the background. A clear and straightforward pattern depicts the cablaka of Banyumas community that is a characteristic of this batik. Banyumasan Batik motifs along with the meaning and value contained within are as follow.

\subsection{Typical Motifs of Banyumas}

Banyumasan Batik has three types of typical motifs. The first motif was inspired by the environment in the form of flora including the motifs of Lumbon, Jahe Srimpang, Sekar Surya, Godong Kosong, Serayuan, Pring Sedhapur, and Tirta Teja. The second motif was inspired by the fauna within the environment, including Ayam Puger, Babon Angrem, and Gemek Satekem. The other motifs that imitate other regions are Sida Luhur, Sekar Jagad, and Udan Riris which are inspired by batik motifs from Mataraman.

\subsection{Flora Motifs}

\section{Lumbon Motif}

Gondhong Lumbu, usually called as taro leaves, is one of the plants in Banyumas. This plant is found around the Serayu River and able to grow anywhere. It is usually used as a food ingredient under the name 'buntil'. These leaves describe the people who are able to adapt or blend without discrimination. This motif has the meaning that someone must be able to meet the needs of the family without relying on others.

\section{Jahe Srimpang Motif}

Jahe Srimpang motif is one of the flora motifs. Jae (ginger), called as 'jahe' in Bahasa, has benefits as a traditional medicine. Srimpang or Serimpang in Banyumas means palm. This motif has the meaning of human as social being must help each other or having mutual cooperation just like five fingers in one hand palm. Banyumas people always uphold the five pillars of Islam and the five precepts of Pancasila for the sake of the integrity of living together.

\section{Sekar Surya Motif}

Sekar Surya is derived from the words Sekar which means flower and Surya which means sun. This batik motif has an irregular pattern and a combination of various colors. The brown color represents the color of the ground which symbolizes democracy or earthiness. It also means that the Banyumas community, whom are simple and easy to blend in with, can give 
blessings to other people. The golden yellow symbolizes hope for gold, success and the glory of dignity and behavior in which we live. Surya or the sun represents the hope of a bright future for its user. The sun also symbolizes the light that contains the hope to live this life by always getting the bright light from the divine guidance.

\section{Serayuan Motif}

Serayuan is a serpentine river motif. Described in zig-zag form and equipped with supporting motifs as decorations like fish and crustaceans. There are also some additional supporting motifs in the form of flora or plants. A simple patterned motif gives the impression of people's earthiness. A large river with the flowing water divides the Banyumas regency. The river is a source of life for the local residents as well as a source of livelihood and for various other purposes. Batik motif has a meaning of sustainable Banyumas community life. Fish and shrimp describe Banyumas communities whom interact with each other, as do fish and shrimp live in water. The red color in this motif illustrates prosperity which means that Banyumas people always live in prosperity.

\section{Godong Kosong Motif}

Godong Kosong motifs describe types of plants ranging from twigs to flowers. The main motifs are leaves and flowers while the supporting motifs are the series of leaves and branches. Godong Kosong is taken from two words namely Godong which means leaf and Kosong which means there is no content (empty). Therefore, the meaning of Godong Kosong is an empty leaf or empty place. The meaning contained in this motif is a place that is used by the community in the ritual process without interruption. Godong Kosong motif has black as the basic color which means unyielding and eternity, just like the Banyumas community who do not give up easily in getting something they aspire to.

\section{Pring Sedapur Motif}

Pring Sedapur has a meaning of the groups of bamboo trees, in which are easily found within Banyumas area. This motif has the shape of a collection of bamboo trees with the green colors depicting Banyumas community who are still interrelated with each other also with the surrounding environment to preserve fertility. Bamboo, which is bowing the top while getting older, describing a community that is always humble with what they already have.

\section{Tirta Teja Motif}

Tirta Teja has the meaning of Tirta (water) and Teja (light). Therefore, Tirta Teja is a clear water that looks like light. There are many clean water sources in Banyumas, such as Baturraden at the foot of Mount Slamet. The shape of the zig-zag motif in a straight direction and the brown color depicts the Banyumas community who are always patient to go through the twists and turns of this life in order to return to the straight or right path. This motif will show the prestige of the user when it is used.

\section{Fauna Motifs}

\section{Ayam Puger Motif}

Ayam Puger Motif is one of the batik motifs inspired by animals namely Ayam (roosters) as well as the shape of the house. In Banyumas, Puger means 'pathokan' or the role model. This motif has the meaning that Banyumas community, especially men, become a role model for their families as a picture of a rooster. The shape of the house has the meaning that the extent to which Banyumas people go (wander), they must always keep in their mind about the family and where their origin was born. 


\section{Babon Angrem Motif}

Babon Angrem motif is one of the poultry motifs, i.e. the hatching hen. Babon in the Banyumas language is a hen, while Angrem means incubating. This motif has the meaning that the people of Banyumas have the character of "seneng tapa brata" i.e. happy to be concerned in struggling to protect something very valuable. This is illustrated in the hen being hatching (incubating) her eggs.

\section{Gemek Setekem Motif}

Gemek Setekem derived from two words namely 'gemek' which means quail and 'setekem' which means a fist of hand. Gemek setekem means the quail that is about the size of a fist. Gemek Setekem motif has the main motif of quail and this motif is the characteristic of the area that has a population of many quails. Animals that like to wander in nature describe a society that upholds an attitude of independence in running their lives and is easy to adapt to the environment and new atmosphere.

\subsection{Motifs with the Influence of the Palace}

\section{Sida Mukti Motif}

Sida Mukti is a classic batik motif. The colors on Sida Mukti fabric are soga or brown. Sida has the meaning of really happening or a hope, while Mukti means happiness, power, respect, and no lack of anything. Sida Mukti is a prayer or hope. Batik Sida Mukti is usually used in weddings. Within the Sida Mukti motif, there is a butterfly ornament. Butterflies are beautiful animals. The butterfly can fly high, so it becomes a symbol of hope. The community believes that if you use the Sida Mukti motif cloth on your wedding, all prayers and wishes will be fulfilled to achieve the happiness.

\section{Sida Luhur Motif}

Motifs that begin with Sida are motifs that are often made by batik makers. In this motif, there is the main ornament in the form of eagle or lar which symbolizes the sun. Javanese culture in the character of the solar deity symbolizes fortitude. There is a main ornament in the form of a bird that symbolizes the world of the symbol of the god of Bayu which means fortitude. Like Sida Mukti, Sida Luhur is a motif that has the meaning of an expectation that is expected to actually occur. The difference is only a little in the basic color. The basic color of the fabric is black and is only used in sadranan and funeral rites. Banyumas people usually use Sidoluhur batik cloth when there is a death ceremony as a form of respect for their ancestors.

\section{Sekar Jagad Motif}

Sekar Jagad motif symbolizes the beauty of the world so that anyone who sees this motif will feel enchanted by the beauty of the world. The Sekar Jagad motif comes from the word "kar jagad" which is in Javanese, kar: map, jagad: world. Therefore, this motif also symbolizes diversity throughout the world. On a piece of batik cloth, Sekar Jagad found having a meaning about the harmonious relationship between humans and the Creator, humans with nature, and also with each other so that Banyumas people still uphold the values of customs. There is also a strong tolerance among religious people, so they can live in harmony together. 


\section{Udan Riris Motif}

In Banyumasan language, Udan Riris means a light rain. A long time ago, when one of the batik makers was doing their routine, suddenly a light rain came. Afterwards, the batik mimics the shape of the drizzle. This motif depicts people who are always grateful for favors given by the Almighty God.

\section{Conclusion}

Banyumasan Batik has typical and firm motifs. Patterns and colors inspired by plants and animals with dark colors characterizing the inland batik. The philosophy of each motif is rooted in exploring the value and meaning of life. The meaning presented in the aesthetic wrapper is implied semiotically in a batik's canting stroke. Typical developing batik motifs consist of Lumbon (spice), Jahe Serimpang, Sekar Surya, Serayuan, Pring Sedapur, Tirtatejo, Godong Kosong, Ayam Puger, Babon Angrem, Gemek Setekem, Sida Mukti, Sida Luhur, Sekar Jagad, and Udan Riris. The meaning contained in the motif shows the cultural political identity that developed in the Banyumas community.

\section{References}

[1] I. M. Sholikhah, D. R. Purwaningsih, and E. Wardani, "Makna Simbolis Motif Batik Banyumas Sebagai Realisasi Nilai Kearifan Lokal Masyarakat,” Pros. Semin. Nas. dan Call Pap., vol. 6, pp. 1397-1404, 2017

[2] D. Martin, "Semiotika Batik Kompeni Cirebon," DEIKSIS, vol. 5, no. 2, pp. 150-160, 2013.

[3] R. P. Chairiyani, "Semiotika Batik Larangan di Yogyakarta," Humaniora, vol. 5, no. 2, pp. 1177 1186, 2014.

[4] Y. A. Piliang, "Semiotika Teks : Sebuah Pendekatan Analisis Teks," Mediator, vol. 5, no. 2, pp. 189-198, 2004.

[5] N. A. Putri, "Penanaman Nilai-Nilai Pendidikan Karakter Melalui Mata Pelajaran Sosiologi," J. Komunitas, vol. 3, no. 2, pp. 205-215, 2011.

[6] G. R. Somantri, "Memahami Metode Kualitatif," Makara, Sos. Hum., vol. 9, no. 2, pp. 57-65, 2005. 